\title{
35 years of the classification of Rezende: the importance of esophagogram in the context of Chagas disease in Brazil
}

\author{
Ricardo Vieira TELES FILHO', Lucas Henrique Souza de AZEVÊDO² and Guilherme de Matos ABE²
}

Received 20/12/2018 Accepted 15/1/2019

HEADINGS - Esophageal achalasia. Chagas disease. Deglutition disorders. Radiography, classification.

\section{Mr. Editor,}

Achalasia is a disorder of the lower esophagus in which its sphincter is unable to relax even during a peristaltic reflex. Its development is related to the loss of both Auerbach's (myenteric) and Meissner's (submucous) plexuses of the distal esophagus and lower sphincter, due to a neurodegenerative process that may be autoimmune or secondary to an infection. In Brazil, Chagas disease is one of this disorder's main etiologies, by promoting the destruction of the myenteric plexus due an inflammatory response to the Trypanosoma cruzi. The Chagas megaesophagus is one of its presentations, consisting of the addition of achalasia to ineffective peristalsis that results in esophageal dilatation ${ }^{(1)}$.

The world's incidence of achalasia is about 1/100,000 and, because of its chronicity, its prevalence is about 9 to $10 / 100,000$. It is estimated that, currently, about 1 million chronic Chagas patients live in Brazil. Megaesophagus affects about $7 \%$ to $10 \%$ of these patients, manifesting during about 20 to 40 years old ${ }^{(1-3)}$. The main symptom of this condition is the long-lasting dysphagia, that may be followed by regurgitation, retrosternal pain, heartburn and sialorrhea. When facing symptoms like dysphagia, it is necessary, at first, to exclude diagnostic hypothesis of gastroesophageal reflux disease, mechanical obstruction of esophagus, or malignancy, since those are more prevalent; then, it must be proceeded the investigation of esophageal motility disorders, such as achalasia ${ }^{(4)}$.

Because of this illness' importance in our setting, and because of the need of accessible radiologic methods that allow diagnosis, classification and follow-up of patients, the barium-based contrast radiography of the esophagus (esophagogram) is still highlighted in the spite of more modern methods. The contrast radiography of the esophagus almost always confirms the diagnosis of megaesophagus ${ }^{(5)}$, and it can be used to classify the case's severity according to the classification of Rezende. (FIGURE 1).

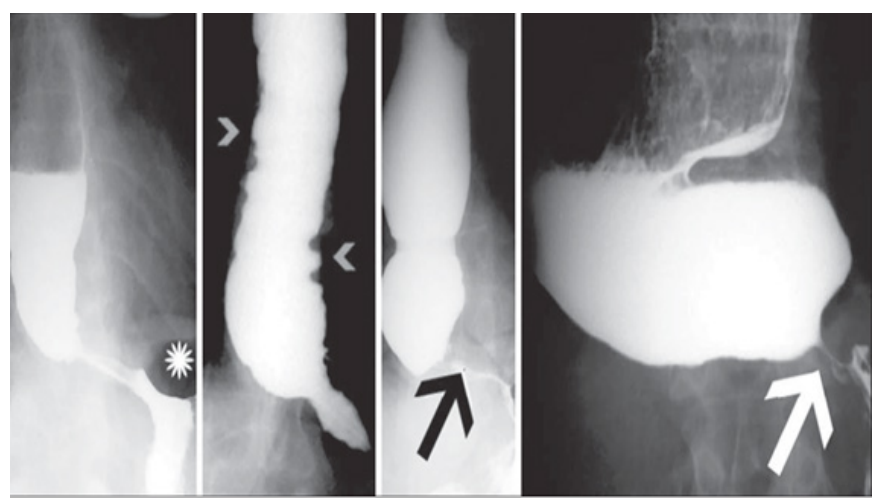

FIGURE 1. Radiologic groups of the Chagas esophagopathy according to the classification of Rezende. From left to right: group I - unchanged caliber, discreet contrast retention (asterix - gastric bubble); group II - moderate increase of caliber, contrast retention and tertiary waves; group III - large increase of caliber and hypotonia; group IV - dolico-megaesophagus ${ }^{(3)}$.

In commemoration of the 35 years of this classification, developed by the emeritus professor of our school, we write this letter aiming to reiterate its singularly relevant attributes: it is based on an accessible radiographic technic in the context of Brazil's radiologic services, it is genuinely Brazilian, it is useful in our hardships, and it uses simple criteria to compose an objective and assertive analysis for the continuity of the patient's follow-up ${ }^{(5,6)}$.

Declared conflict of interest of all authors: none

Disclosure of funding: no funding received

Research performed at: Department of Radiology and Diagnostic Imaging of the Faculty of Medicine of the Federal University of Goiás, Brazil.

1 Universidade Federal de Goiás, Faculdade de Medicina, Departamento de Radiologia e Diagnóstico por Imagem, Goiânia, GO, Brasil. ${ }^{2}$ Universidade Federal de Goiás, Faculdade de Medicina, Goiânia, GO, Brasil.

Corresponding author: Ricardo Vieira Teles Filho. E-mail: ricardovteles@gmail.com 
It should be emphasized that, even though there are several technological advances in the field of diagnosis of esophageal impairment due to Chagas, such as the highresolution esophageal manometry, as well as new reclassifications of megaesophagus, such as those which utilize physiological criteria, the utility of the classification of Rezende remains paramount for the operatory orientation of the illness amongst Brazilian surgeons ${ }^{(7)}$.

This classification evaluates changes of motility (presence of tertiary waves, and hypokinesia and akinesia), slowing of the emptying velocity, changings of caliber, and presences of liquids and barium and presence of the "bird beak" sign. Once the imaging is analyzed, the patient is clas- sified in degrees I-IV. It is believed that a well-done clinical history added to positive serologic testing for Chagas and radiologic changes in the simple and filmed esophagogram are sufficient for diagnosing the disease ${ }^{(3,8)}$. Therefore, when applied to clinical-epidemiologic setting that points out to Chagas disease, the classification of Rezende, through the esophagogram, is an extremely useful and accurate tool to consolidate this diagnosis.

\section{Orcid}

Ricardo Vieira Teles Filho: 0000-0003-4822-1526.

Lucas Henrique Souza de Azevêdo: 0000-0002-2629-492X.

Guilherme de Matos Abe: 0000-0002-2446-3750.

Teles Filho RV, Azevêdo LHS, Abe GM. 35 anos da classificação de Rezende: a importância do esofagograma no contexto da doença de Chagas no Brasil. Arq Gastroenterol. 2019;56(1):106-7.

DESCRITORES - Acalasia esofágica. Doença de Chagas. Transtornos de deglutição. Radiografia, classificação.

\section{REFERENCES}

1. Pandolfino JE, Gawron AJ. Achalasia: A systematic review. JAMA - J Am Med Assoc. 2015;313:1841-52.

2. Brasi. Ministério da Saúde. Doença de Chagas: o que é, causas, sintomas, tratamento e prevenção. 2017.

3. Abud TG, Abud LG, Vilar VS, Szejnfeld D, Reibscheid S. Alterações radiológicas encontradas no megaesôfago chagásico em radiografias simples de tórax e esofagogramas. Radiol Bras. 2016;49:358-62.

4. Rezende JM De. O aparelho digestivo na doença de chagas: Mem Inst Oswaldo Cruz. 1984;79:97-106.
5. Rezende JM, Lauar KM OA. Aspectos clínicos e radiológicos da aperistalsis do esôfago. Rev Bras Gastroenterol. 1960;12:247-62.

6. JM. R. Classificação radiológica do megaesôfago. Rev Goiana Med. 1982;28:187-91.

7. Meneghelli UG, Peria FM, Darezzo FMR, Almeida FH, Carla M, Aprile LRO, et al. Clinical, radiographic, and manometric evolution of esophageal involvement by Chagas' disease. Dysphagia. 2005;45:40-5.

8. Tuason J, Inoue H. Current status of achalasia management: a review on diagnosis and treatment. J Gastroenterol. 2017;52:401-6. 